Check for updates

Cite this: RSC Adv., 2021, 11, 19500

\title{
A "one pot" mass spectrometry technique for characterizing solution- and gas-phase photochemical reactions by electrospray mass spectrometry $\dagger$
}

\author{
Rosaria Cercola, (D) Natalie G. K. Wong, (D) Chris Rhodes, Lorna Olijnyk, \\ Neetisha S. Mistry, Lewis M. Hall, Jacob A. Berenbeim, (D) Jason M. Lynam (D) \\ and Caroline E. H. Dessent (DD*
}

\begin{abstract}
The characterization of new photochemical pathways is important to progress the understanding of emerging areas of light-triggered inorganic and organic chemistry. In this context, the development of platforms to perform routine characterization of photochemical reactions remains an important goal for photochemists. Here, we demonstrate a new instrument that can be used to characterise both solution-phase and gas-phase photochemical reactions through electrospray ionisation mass spectrometry (ESI-MS). The gas-phase photochemistry is studied by novel laser-interfaced mass spectrometry (LIMS), where the molecular species of interest is introduced to the gas-phase by ESI, mass-selected and then subjected to laser photodissociation in the ion-trap. On-line solution-phase photochemistry is initiated by LEDs prior to ESI-MS in the same instrument with ESI-MS again being used to monitor photoproducts. Two ruthenium metal carbonyls, $\left[\mathrm{Ru}\left(\eta^{5}-\mathrm{C}_{5} \mathrm{H}_{5}\right)\left(\mathrm{PPh}_{3}\right)_{2} \mathrm{CO}\right]\left[\mathrm{PF} \mathrm{F}_{6}\right]$ and $\left[\mathrm{Ru}\left(\eta^{5}-\mathrm{C}_{5} \mathrm{H}_{5}\right)(\mathrm{dppe}) \mathrm{CO}\right]\left[\mathrm{PF}_{6}\right]$ (dppe = 1,2-bis(diphenylphosphino)ethane) are studied using this methodology. We show that the gas-phase photofragmentation pathways observed for the ruthenium complexes via LIMS (i.e. loss of $\mathrm{CO}+\mathrm{PPh}_{3}$ ligands from $\left[\mathrm{Ru}\left(\eta^{5}-\mathrm{C}_{5} \mathrm{H}_{5}\right)\left(\mathrm{PPh}_{3}\right)_{2} \mathrm{CO}\right]^{+}$and loss of just $\mathrm{CO}$ from $\left.\left[\mathrm{Ru}\left(\eta^{5}-\mathrm{C}_{5} \mathrm{H}_{5}\right)(\mathrm{dppe}) \mathrm{CO}\right]^{+}\right)$mirror the solution-phase photochemistry at $3.4 \mathrm{eV}$. The advantages of performing the gas-phase and solution-phase photochemical characterisations in a single instrument are discussed.
\end{abstract}

Received 1st April 2021

Accepted 17th May 2021

DOI: $10.1039 / \mathrm{d} 1 \mathrm{ra02581c}$

rsc.li/rsc-advances recently, a number of on-line photolysis set ups have been demonstrated that dramatically enhance the potential of mass spectrometry as a tool for monitoring photochemical reactions. ${ }^{12-14}$

In this paper, we describe the application of an instrument that combines on-line photolysis with electrospray ionization mass spectrometry detection and laser-interfaced mass spectrometry (LIMS) to study the photodissociation of CO from metal carbonyl compounds. For the first time, this experiment provides a "one-pot" tool for characterising the solution-phase and gas-phase photochemistry of a system. While the solution-phase measurement provides insight into the realworld photochemistry, the accompanying gas-phase measurement can significantly aid the understanding of the solutionphase mechanism, as well as being directly comparable to high-level quantum chemical calculations. The intrinsic photochemical pathway can also be easier to follow away from the complications of the condensed phase environment. For example, solvation of photochemically generated singlet 16electron $\mathrm{d}^{6}$ metal complexes occurs on a sub-ps timescale so
Department of Chemistry, University of York, Heslington, York YO10 5DD, UK. E-mail: caroline.dessent@york.ac.uk

$\dagger$ Electronic supplementary information (ESI) available. See DOI: $10.1039 / \mathrm{d} 1 \mathrm{ra} 02581 \mathrm{c}$ trometer for analysis. ${ }^{7,8}$ This is despite the fact that it has been widely used to investigate non-photochemical reactions. ${ }^{9-11}$ Very 
that direct observation of the initial photoproducts in the condensed phase is challenging. ${ }^{15}$

The first report of the use of electrospray ionisation mass spectrometry (ESI-MS) to detect intermediates from a photoinitiated reaction in solution was from Arakawa et al. ${ }^{16}$ The study focused on solvolysis of ruthenium complexes, and was able to demonstrate that photoinitiated solvolysis, triggered in the electrospray plume, proceeds by an addition-elimination reaction. Turner et al. and co-workers used a similar approach, involving irradiation at the tip of the spray capillary, to study iron cyclopentadienyl complexes catalysing epoxides. ${ }^{17}$ More recently, Badu-Tawiah and co-workers, Chen and co-workers, as well as Roithová and co-workers have employed irradiation in the ESI spray region to characterise the intermediates of photoinitiated catalysis reactions. ${ }^{12-14}$ All of these studies demonstrated that ESI-MS can be used to detect the intermediates of solution-phase photoinitiated reactions, with the caveat that the half-life must be above $\sim 10 \mathrm{~ms}$. We note that in-source diode light activation was also used by Barran and co-workers to explore the conformational diversity of the UVR8 photoreceptor. $^{18}$

Gas-phase photochemistry experiments that combine photoexcitation and mass spectrometric detection are numerous, although the focus of many of these studies has been on spectroscopy of the mass-selected molecules and clusters rather than the photochemical products. ${ }^{19}$ To provide some specific photochemical examples from this field, Jockusch and Brøndsted Nielsen have studied luminescence of massselected ions, ${ }^{\mathbf{2 0 , 2 1}}$ and Bieske has employed ion mobility mass spectrometry to study photoswitching reactions. ${ }^{22}$

We focus here on two ruthenium metal carbonyls, $\left[\mathrm{Ru}\left(\eta^{5}\right.\right.$ $\left.\left.\mathrm{C}_{5} \mathrm{H}_{5}\right)\left(\mathrm{PPh}_{3}\right)_{2} \mathrm{CO}\right]\left[\mathrm{PF}_{6}\right]$ and $\left[\mathrm{Ru}\left(\eta^{5}-\mathrm{C}_{5} \mathrm{H}_{5}\right)(\mathrm{dppe}) \mathrm{CO}\right]\left[\mathrm{PF}_{6}\right](\mathrm{dppe}=$ 1,2-bis(diphenylphosphino)ethane) (Scheme 1). Substituted metal carbonyls are widely studied for their photoreactivity, since they are excellent photocatalysts (and precursors) for organic reactions, ${ }^{23,24}$ as well as intermediates for the synthesis of organometallic compounds..$^{25}$ In a number of recent highprofile studies, they were also being investigated for the photocatalytic reduction of $\mathrm{CO}_{2}$ to $\mathrm{CO}$ or formic acid ${ }^{26-28}$ and to probe the mechanistic pathways that lead to $\mathrm{C}-\mathrm{C}$ and $\mathrm{C}-\mathrm{H}$ bond formation. ${ }^{29,30}$ The use of metal carbonyls as CO-releasing molecules (CORMs) is also a promising area of research in medicinal chemistry. ${ }^{31-37}$ Ruthenium half-sandwich complexes have found particular applications in transfer-hydrogenation and alcohol oxidation catalysis, ${ }^{38-40} \mathrm{C}-\mathrm{H}$ bond functionalisation, ${ }^{41}$ as well as in cancer phototherapy. ${ }^{42,43}$
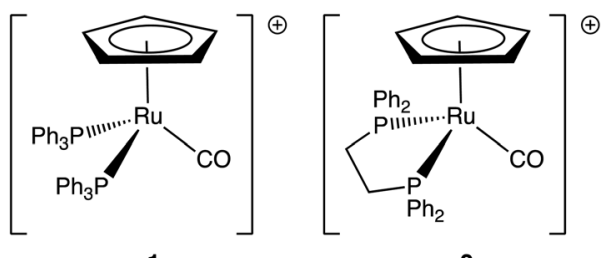

1 2

Scheme 1 Structures of (1) $\left[\mathrm{Ru}\left(\eta^{5}-\mathrm{C}_{5} \mathrm{H}_{5}\right)\left(\mathrm{PPh}_{3}\right)_{2} \mathrm{CO}\right]^{+}$and (2) $\left[\mathrm{Ru}\left(\eta^{5}-\right.\right.$ $\left.\left.\mathrm{C}_{5} \mathrm{H}_{5}\right)(\mathrm{dppe}) \mathrm{CO}\right]^{+}$.
The CO-releasing properties of metal carbonyl complexes can be tuned to achieve maximum $\mathrm{CO}$ photorelease at the required wavelengths by applying the principles of rational design. The metals that are chosen in this study are in a lowspin $\mathrm{d}^{6}$ configuration, and can, therefore, access metal-toligand charge-transfer transitions (MLCT) leading to $\mathrm{M}-\mathrm{CO}$ labilisation and $\mathrm{CO}$ release. The use of conjugate ancillary ligands, with low-lying $\pi^{*}$ orbitals, can shift the absorption wavelength to the red, compared to homoleptic metal carbonyls. ${ }^{44}$ However, it is desirable to have robust theoretical methods that can predict such photochemistry, and gas-phase studies are of enormous benefit in this context as they can be readily compared with computational results. ${ }^{44-46}$ In this work, we investigate the intrinsic (i.e., gas-phase) CO releasing photochemistry of two metal carbonyls via laser-interfaced mass spectrometry (LIMS), ${ }^{47,48}$ and demonstrate the ability to combine this with online solution-phase photochemistry conducted consecutively in the same instrument. Our novel gasphase LIMS technique measures all the ionic photoproducts simultaneously with the gaseous absorption spectrum, thus providing a direct measurement of the number of $\mathrm{CO}$ units ejected per photon-interaction with the molecule along with the identity of the primary photofragments. ${ }^{37}$

\section{Experimental}

\section{Chemicals}

All chemicals were synthesised according to previously published protocols. ${ }^{49}$

\section{Laser-interfaced mass spectrometry (gas-phase photochemistry)}

Gas-phase UV photodissociation experiments were conducted in a laser-interfaced [Nd:YAG $(10 \mathrm{~Hz}$, Surelite) pumped OPO (Horizon)] amaZon ion-trap mass spectrometer (LIMS), which was modified as described in detail elsewhere. ${ }^{47,50}$ The UV spectra were acquired across the range 3.2-5.2 eV (360-238 nm) at $\sim 1 \mathrm{~mJ}$ laser power. A laser step size of $1 \mathrm{~nm}$ was employed for all scans. Photodepletion intensity (PD) and photofragment production (PF) were calculated using eqn (1) and (2):

$$
\begin{gathered}
\text { Photodepletion intensity }=\frac{\ln \left(\frac{\operatorname{Int}_{\mathrm{OFF}}}{\text { Int }_{\mathrm{ON}}}\right)}{\lambda \times P} \\
\text { Photofragmentation intensity }=\frac{\ln \left(\frac{\text { Int }_{\mathrm{FRAG}}}{\text { Int }_{\mathrm{OFF}}}\right)}{\lambda \times P}
\end{gathered}
$$

Here, Int ${ }_{\mathrm{ON}}$ and Int $\mathrm{OFF}_{\mathrm{OF}}$ are the parent ion intensities with laser

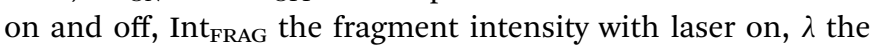
excitation wavelength $(\mathrm{nm})$ and $P$ the laser pulse energy $(\mathrm{mJ})$. The photodepletion spectrum is considered to be equivalent to the gaseous absorption spectrum in the limit where fluorescence is negligible. Quantum ion yields are calculated according to eqn (3):

$$
\text { Ion yield }=\mathrm{Int}_{\mathrm{FRAG}} / \sum \mathrm{Int}_{\mathrm{PFT}}
$$


where Int $_{\mathrm{PFT}}$ is the sum of the photofragment ion intensities obtained with the laser on. Higher-energy collisional dissociation (HCD) was performed to investigate the ground-state fragmentation of $\left[\mathrm{Ru}\left(\eta^{5}-\mathrm{C}_{5} \mathrm{H}_{5}\right)\left(\mathrm{PPh}_{3}\right)_{2} \mathrm{CO}\right]^{+}$and $\left[\mathrm{Ru}\left(\eta^{5}\right.\right.$ $\mathrm{C}_{5} \mathrm{H}_{5}$ )(dppe)CO $]^{+}$to complement the LIMS measurements $\left(10^{-6} \mathrm{M}\right.$ solution in DCM : MeOH $\left.3: 1\right)$. An Orbitrap ${ }^{\mathrm{TM}}$ Fusion Tribrid mass spectrometer (Thermo Fisher Scientific, Waltham, MA, U.S.A.) was used, as previously described. ${ }^{51}$ HCD breakdown curves were recorded for energies between 0 and $40 \%$. Further details of ESI settings employed are given in Section S2 of the ESI. $\dagger$

\section{Online photolysis cell and software}

The online photolysis cell was 3D printed (using Autodesk Fusion 360 CAD software and a Makerbot Replicator $2 \times$ printer) in the shape of a hollow cuboid (ESI, Section S1, Fig. S1†). On the four long faces LEDs (LuxiGen LZ1 manufactured by LEDEngin, California) of different wavelengths (365, 400, 460 and $523 \mathrm{~nm}$ ) were mounted in designated cavities. On the two small faces, end caps were printed to access the inside of the cell, which was covered in self-adhesive foil to maximise irradiation from the LEDs (Fig. S1a $\dagger$ ). Holes were drilled in the end caps to accommodate a UV transparent fused silica capillary tubing (100 $\mu \mathrm{m}$ ID, $375 \mu \mathrm{m}$ OD, Molex/Polymicro Technologies, Phoenix, AZ) connected, on one side, to the syringe pump via PEEK tubing and on the other, to the ESI needle on top of which the device was mounted (Fig. S1b $\dagger$ ). The photolysis cell was controlled with LabVIEW software and an Arduino Nano microcontroller to allow the adjustment of the brightness of one or more LEDs at a time. The individual LED current could be varied from 0 to 1 (where 1 is equal to $700 \mathrm{~mA}$ ) (Fig. S2 $\dagger$ ). For the current study, only the $365 \mathrm{~nm}$ LED was used, which has a maximum power of $1360 \mathrm{~mW}$ with a current of $700 \mathrm{~mA}$.

\section{Online photolysis experiment}

$\left[\mathrm{Ru}\left(\eta^{5}-\mathrm{C}_{5} \mathrm{H}_{5}\right)\left(\mathrm{PPh}_{3}\right)_{2} \mathrm{CO}\right]\left[\mathrm{PF}_{6}\right]$ and $\left[\mathrm{Ru}\left(\eta^{5}-\mathrm{C}_{5} \mathrm{H}_{5}\right)(\mathrm{dppe}) \mathrm{CO}\right]\left[\mathrm{PF}_{6}\right]$ were electrosprayed at $100{ }^{\circ} \mathrm{C}$ from $10^{-5} \mathrm{~mol} \mathrm{~L}^{-1}$ solutions (mixed DCM : $\mathrm{MeOH}$ in the ratio $3: 1$ ) and analysed in positive ion mode. Solution-phase photofragmentation spectra were obtained via irradiation of the solutions with the online photolysis cell. The syringe pump flow rate was $0.25 \mathrm{ml} \mathrm{h}^{-1}$, and the mass spectra were acquired continuously. A baseline mass spectrum (total ion current) of the solution was acquired for a minute before turning on the LED to provide a background spectrum. Once the LED was turned on, the flow rate was kept constant, allowing irradiation of the solution as it travelled towards the ESI needle.

\section{Results and discussion}

Fig. 1a and b show the ESI-MS of complexes 1 and 2, respectively, run in positive ion mode. We note that the low intensity of fragment ions in these spectra indicates that the parent compounds are representatively transformed from solution to the gas-phase, and do not readily fragment within the source or during the electrospray process.

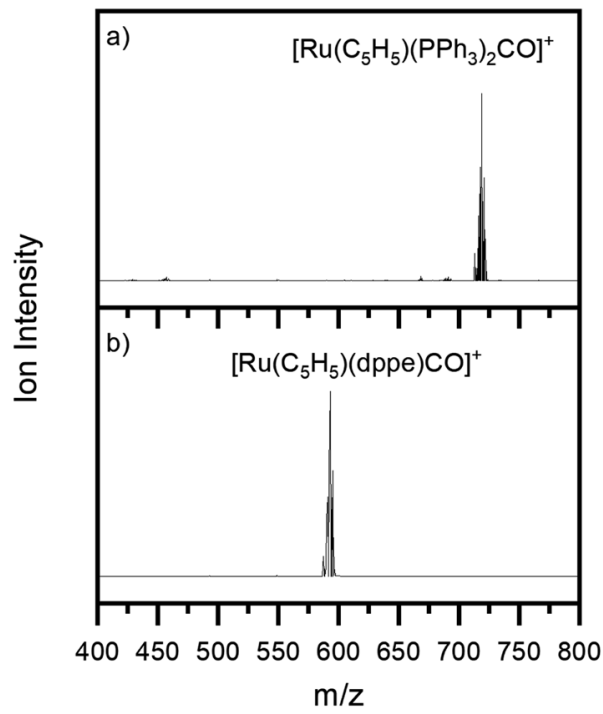

Fig. 1 Positive ion mode electrospray mass spectrum of solutions of (a) $\left[\mathrm{Ru}\left(\eta^{5}-\mathrm{C}_{5} \mathrm{H}_{5}\right)\left(\mathrm{PPh}_{3}\right)_{2} \mathrm{CO}\right]\left[\mathrm{PF}_{6}\right]$ and (b) $\left[\mathrm{Ru}\left(\eta^{5}-\mathrm{C}_{5} \mathrm{H}_{5}\right)(\mathrm{dppe}) \mathrm{CO}\right]\left[\mathrm{PF}_{6}\right]$, illustrating complexes 1 and 2, respectively. The isotopic patterns observed are indicative of complexes containing a single ruthenium atom (Section S3†).

Solution and gas-phase absorption spectra of $\left[\mathrm{Ru}\left(\eta^{5}\right.\right.$ $\left.\left.\mathrm{C}_{5} \mathrm{H}_{5}\right)\left(\mathrm{PPh}_{3}\right)_{2} \mathrm{CO}\right]^{+}$and $\left[\mathrm{Ru}\left(\eta^{5}-\mathrm{C}_{5} \mathrm{H}_{5}\right)(\mathrm{dppe}) \mathrm{CO}\right]^{+}$

The gas-phase absorption spectra of $\left[\mathrm{Ru}\left(\eta^{5}-\mathrm{C}_{5} \mathrm{H}_{5}\right)\left(\mathrm{PPh}_{3}\right)_{2} \mathrm{CO}\right]^{+}$ and $\left[\mathrm{Ru}\left(\eta^{5}-\mathrm{C}_{5} \mathrm{H}_{5}\right)(\mathrm{dppe}) \mathrm{CO}\right]^{+}$obtained via photodepletion of the mass-selected precursor ions (Fig. 1) are presented in Fig. 2a and $b$. We note that the gas-phase photolysis experiments were conducted on the cationic chromophores, $\mathbf{1}$ and $\mathbf{2}$, whereas the anionic $\mathrm{PF}_{6}{ }^{-}$counterions were also present in solution. The presence, or absence, of these counterions will not affect the absorption spectra.

Both 1 and 2 have very similar absorption spectra, and display three distinct bands which are labelled I, II and III peaking at $\sim 3.9,4.6$ and $5.1 \mathrm{eV}$ for 1 and $\sim 4.0,4.5$ and $5.2 \mathrm{eV}$ for 2. Band II for complex $\mathbf{1}$ (Fig. 2a) is more clearly visible in the photofragmentation action spectrum of this species (Fig. 5a). Fig. 2c and d display the solution-phase absorption spectra of $\left[\mathrm{Ru}\left(\eta^{5}-\mathrm{C}_{5} \mathrm{H}_{5}\right)\left(\mathrm{PPh}_{3}\right)_{2} \mathrm{CO}\right]\left[\mathrm{PF}_{6}\right]$ and $\left[\mathrm{Ru}\left(\eta^{5}-\mathrm{C}_{5} \mathrm{H}_{5}\right)(\mathrm{dppe}) \mathrm{CO}\right]\left[\mathrm{PF}_{6}\right]$, which are in good agreement with the gas-phase absorption spectra. Several points are of note when comparing the gas- and solution-phase spectra: Firstly, the similar spectral profiles observed for the compounds in the gas-phase and solution demonstrates that the gas-phase spectra were obtained via single-photon photodissociation. Secondly, the fact that no significant solution-induced spectral shift occurs for these compounds means that gaseous and solution excitation energies accessed the same electronic transitions (Section $\mathrm{S} 4 \dagger$ presents time dependent density functional calculations for $\mathbf{1}$ ). Finally, the fact that both spectra are similar confirms that the mass-selected precursor gaseous ion is the major chemical species in the solution-phase, and hence the dominant species that was photolyzed in solution. 

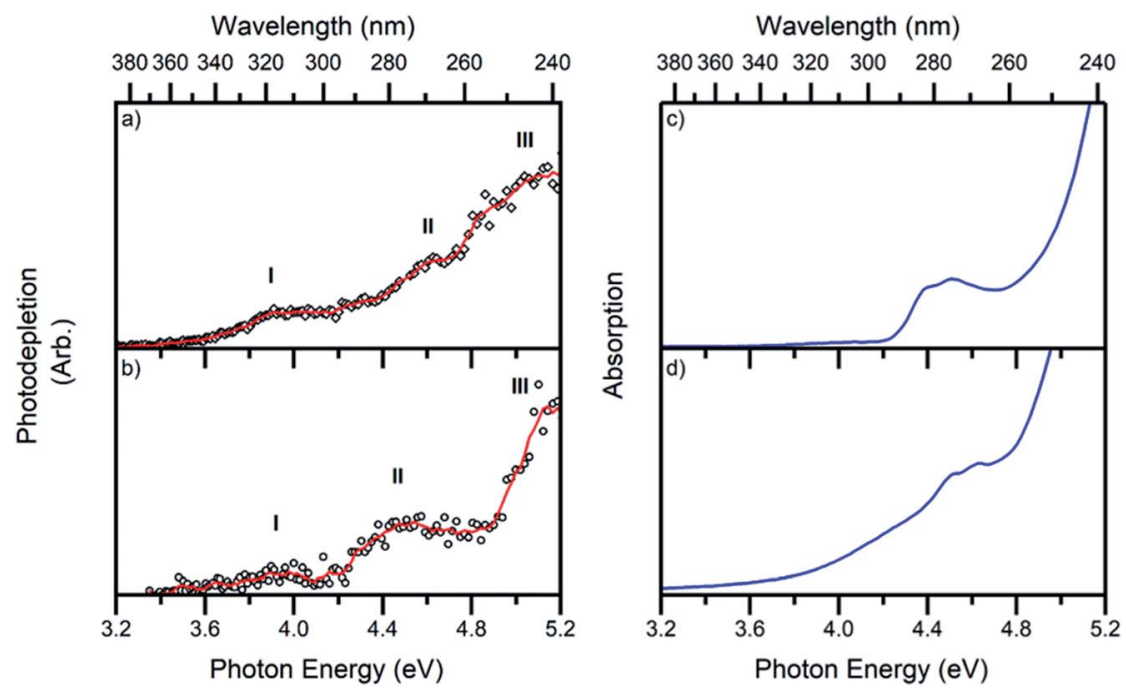

Fig. 2 Photodepletion (gas-phase absorption) spectra of complexes (a) 1 and (b) 2. Spectra were recorded across the range 3.2-5.2 eV. The solid lines are five-point adjacent averages of the data points. Solution-phase absorption spectra of $(c)\left[R u\left(\eta^{5}-\mathrm{C}_{5} \mathrm{H}_{5}\right)\left(\mathrm{PPh}_{3}\right)_{2} \mathrm{CO}\right]\left[\mathrm{PF} \mathrm{F}_{6}\right]$ and $(\mathrm{d})\left[\mathrm{Ru}\left(\eta^{5}-\right.\right.$ $\left.\left.\mathrm{C}_{5} \mathrm{H}_{5}\right)(\mathrm{dppe}) \mathrm{CO}\right]\left[\mathrm{PF}_{6}\right]$ in $\mathrm{DCM}: \mathrm{MeOH}(3: 1)$ between 3.2-5.2 eV.

\section{Photodissociation pathways of $\left[\mathrm{Ru}\left(\eta^{5}-\mathrm{C}_{5} \mathrm{H}_{5}\right)\left(\mathrm{PPh}_{3}\right)_{2} \mathrm{CO}\right]^{+}$and $\left[\mathrm{Ru}\left(\boldsymbol{\eta}^{5}-\mathrm{C}_{5} \mathrm{H}_{5}\right)(\mathrm{dppe}) \mathrm{CO}\right]^{+}$}

Fig. 3 shows the photofragment mass spectra observed following laser photoexcitation of complexes 1 and 2 at $4.6 \mathrm{eV}$ $(270 \mathrm{~nm})$ within the band II region. The main photofragment obtained for complex 1 (Fig. 3a) corresponds to the loss of both a $\mathrm{CO}$ and $\mathrm{PPh}_{3}$ ligand from the precursor ion:

$$
\begin{aligned}
{\left[\mathrm{Ru}\left(\eta^{5}-\mathrm{C}_{5} \mathrm{H}_{5}\right)\left(\mathrm{PPh}_{3}\right)_{2} \mathrm{CO}\right]^{+}+h \nu \rightarrow } & {\left[\mathrm{Ru}\left(\eta^{5}-\mathrm{C}_{5} \mathrm{H}_{5}\right)\left(\mathrm{PPh}_{3}\right)\right]^{+} } \\
& +\mathrm{CO}+\mathrm{PPh}_{3}
\end{aligned}
$$

with additional photofragments being produced corresponding to the photoinduced loss of either $\mathrm{CO}$ or $\mathrm{PPh}_{3}$ :

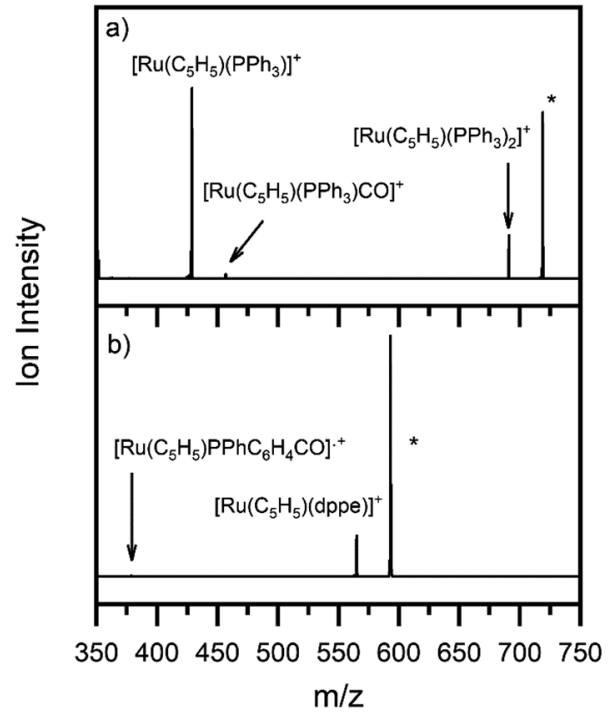

Fig. 3 Photofragment mass spectra of complexes (a) 1 and (b) 2 at $4.6 \mathrm{eV} . *$ indicates the precursor ion.

$$
\begin{aligned}
{\left[\mathrm{Ru}\left(\eta^{5}-\mathrm{C}_{5} \mathrm{H}_{5}\right)\left(\mathrm{PPh}_{3}\right)_{2} \mathrm{CO}\right]^{+}+h \nu \rightarrow } & {\left[\mathrm{Ru}\left(\eta^{5}-\mathrm{C}_{5} \mathrm{H}_{5}\right)\left(\mathrm{PPh}_{3}\right)_{2}\right]^{+} } \\
& +\mathrm{CO} \\
{\left[\mathrm{Ru}\left(\eta^{5}-\mathrm{C}_{5} \mathrm{H}_{5}\right)\left(\mathrm{PPh}_{3}\right)_{2} \mathrm{CO}\right]^{+}+h \nu \rightarrow } & {\left[\mathrm{Ru}\left(\eta^{5}-\mathrm{C}_{5} \mathrm{H}_{5}\right)\left(\mathrm{PPh}_{3}\right) \mathrm{CO}\right]^{+} } \\
& +\mathrm{PPh}_{3}
\end{aligned}
$$

Ejection of $\mathrm{PPh}_{3}$ is undesirable for applications aimed at $\mathrm{CO}$ photorelease, including ligand substitution. ${ }^{52}$ Compound 2 offers a good alternative in this context to compound 1 since dppe is a chelating ligand and is, therefore, less likely to dissociate from the metallic centre. Photoexcitation of 2 at $4.6 \mathrm{eV}$ produced the photofragment mass spectrum shown in Fig. $3 \mathrm{~b}$, with the main photofragment corresponding to the loss of the carbon monoxide unit from the parent ion and the dppe ligand remaining bound to the metal centre:

$$
\begin{aligned}
{\left[\mathrm{Ru}\left(\eta^{5}-\mathrm{C}_{5} \mathrm{H}_{5}\right)(\mathrm{dppe}) \mathrm{CO}\right]^{+}+h \nu \rightarrow } & {\left[\mathrm{Ru}\left(\eta^{5}-\mathrm{C}_{5} \mathrm{H}_{5}\right)(\mathrm{dppe})\right]^{+} } \\
& +\mathrm{CO}
\end{aligned}
$$

Indeed, $\left[\mathrm{Ru}\left(\eta^{5}-\mathrm{C}_{5} \mathrm{H}_{5}\right)(\text { dppe })\right]^{+}$was the most significant photofragment observed across the entire spectral range. $\left[\mathrm{Ru}\left(\eta^{5}-\mathrm{C}_{5^{-}}\right.\right.$ $\left.\left.\mathrm{H}_{5}\right)\left(\mathrm{PPhC}_{6} \mathrm{H}_{4}\right) \mathrm{CO}\right]^{\cdot+}$ was produced as a minor photofragment by a bond breaking in the dppe ligand $(5 \mathrm{~b})$ :

$$
\begin{aligned}
{\left[\mathrm{Ru}\left(\eta^{5}-\mathrm{C}_{5} \mathrm{H}_{5}\right)(\mathrm{dppe}) \mathrm{CO}\right]^{+}+h \nu \rightarrow } & {\left[\mathrm{Ru}\left(\eta^{5}-\mathrm{C}_{5} \mathrm{H}_{5}\right)\left(\mathrm{PPhC}_{6} \mathrm{H}_{4}\right) \mathrm{CO}\right]^{++} } \\
& +\mathrm{PPh}_{2} \mathrm{CH}_{2} \mathrm{CH}_{3}
\end{aligned}
$$

To aid the interpretation of the photofragmentation pathways, it was useful to perform higher-energy collisional dissociation. ${ }^{51}$ This experiment maps out the ground-state fragmentation pathways as a function of internal energy, and can therefore provide insight into the formation pathways of the photofragments. The HCD curves (0-40\% collision energy) obtained for complexes $\mathbf{1}$ and 2 are shown in Fig. 4. Both 
complexes can be seen to be stable in the gas phase, as neither fragments below 10\% HCD energy. Loss of the single CO from compound 1 , (4b), represented only a minor pathway between 10-25\% HCD energy. In contrast, loss of a single $\mathrm{PPh}_{3}$ unit, (4c), is the dominant lower-energy fragmentation channel. These results mirror those of Crawford et al. on the $\left[\mathrm{Ru}_{6} \mathrm{C}(\mathrm{CO})_{16}\left(\mathrm{PPh}_{3}\right)\right.$ $+\mathrm{OMe}]^{-}$system ${ }^{53}$ where the phosphine ligand was also ejected first when the cluster was subjected to collision-induced dissociation. At higher HCD energies $(>20 \%)$, the $\left[\mathrm{Ru}\left(\eta^{5}\right.\right.$ $\left.\left.\mathrm{C}_{5} \mathrm{H}_{5}\right)\left(\mathrm{PPh}_{3}\right)\right]^{+}$ion can be seen to be produced as a secondary fragment concomitant with the reduction in $\left[\mathrm{Ru}\left(\eta^{5}-\mathrm{C}_{5} \mathrm{H}_{5}\right)\left(\mathrm{PPh}_{3}\right)\right.$ $\mathrm{CO}]^{+}$. It is notable that $\left[\mathrm{Ru}\left(\eta^{5}-\mathrm{C}_{5} \mathrm{H}_{5}\right)\left(\mathrm{PPh}_{3}\right)\right]^{+}$is the main photoproduct above $3.4 \mathrm{eV}$ (Fig. 5a), suggesting that it may be produced though photoexcitation initially producing hot $\left[\mathrm{Ru}\left(\eta^{5}-\mathrm{C}_{5} \mathrm{H}_{5}\right)\left(\mathrm{PPh}_{3}\right) \mathrm{CO}\right]^{+}$that subsequently fragments.

For complex 2, the only significant fragment produced over the HCD range studied corresponded to loss of the single CO ligand and production of $\left[\mathrm{Ru}\left(\eta^{5}-\mathrm{C}_{5} \mathrm{H}_{5}\right)(\text { dppe })\right]^{+}(5 \mathrm{a})$. This ion is also the only significant intensity photofragment. At high energies $(>32 \%)$, the $\left[\mathrm{Ru}\left(\eta^{5}-\mathrm{C}_{5} \mathrm{H}_{5}\right)\left(\mathrm{PPhC}_{6} \mathrm{H}_{4}\right) \mathrm{CO}\right]^{\cdot+}$ ion is observed (5b) as a secondary fragment.

Fig. 5 presents a wavelength-dependent picture of the photodissociation pathways of complexes 1 and 2, obtained by displaying the photofragment production mass spectra across the full spectral range of the gas-phase absorption spectrum (Fig. 2). Photofragmentation of $\left[\mathrm{Ru}\left(\eta^{5}-\mathrm{C}_{5} \mathrm{H}_{5}\right)\left(\mathrm{PPh}_{3}\right)_{2} \mathrm{CO}\right]^{+}$ (Fig. 5a) can be seen to follow pathways (4a-4c). The most intense photofragment at all energies was $\left[\mathrm{Ru}\left(\eta^{5}-\mathrm{C}_{5} \mathrm{H}_{5}\right)\left(\mathrm{PPh}_{3}\right)\right]^{+}$, (4a), produced via loss of $\mathrm{CO}$ and $\mathrm{PPh}_{3}$. In contrast, fragmentation of 1 with loss of the CO moiety, (4b), displays a rather flat profile between 3.8-5.2 eV. Loss of a single $\mathrm{PPh}_{3}$ ligand (4c) is a minor channel that shows a modest increase in intensity at the highest energies.

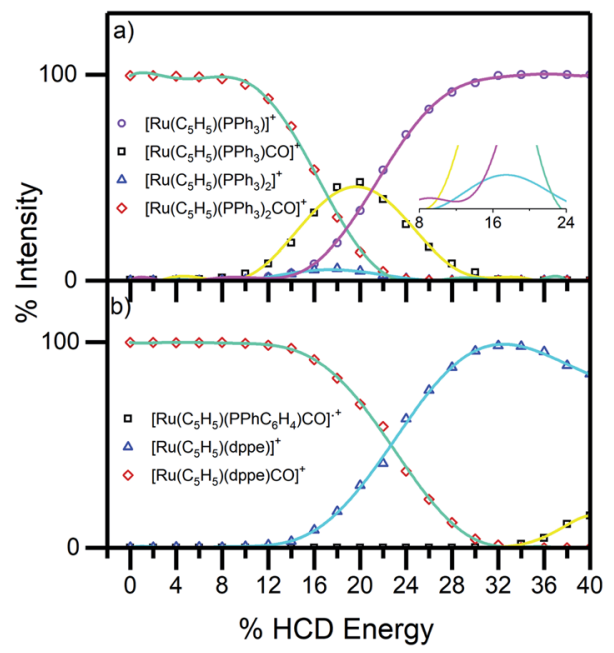

Fig. 4 HCD breakdown curves of complex ions (a) 1 and (b) 2 between $0-40 \% \mathrm{HCD}$ energy, shown with production curves of the resulting fragment ions. The inset in (a) shows the expanded section of the HCD curves between $0-25 \%$ and illustrates $\mathrm{PPh}_{3}$ and $\mathrm{CO}$ loss as in eqn (4b) and $(4 \mathrm{c})$

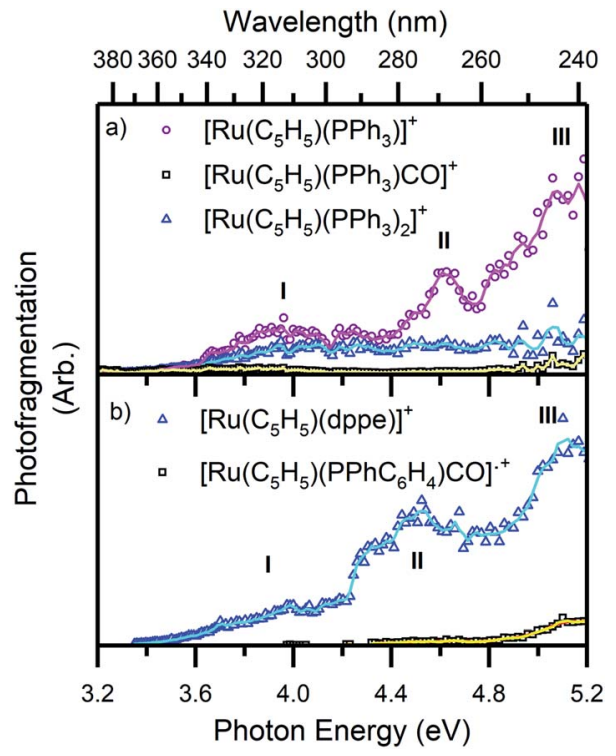

Fig. 5 Photofragment production spectra from the complex ions (a) 1 and (b) 2. Spectra are recorded across the range 3.2-5.2 eV. The solid lines are two-point adjacent averages of the data points.

Fig. 5b displays the photofragment production spectra from complex 2, revealing that the $\left[\mathrm{Ru}\left(\eta^{5}-\mathrm{C}_{5} \mathrm{H}_{5}\right)(\mathrm{dppe})\right]^{+}$photofragment, (5a), was the dominant product ion across the spectral range, with a profile that closely matches the gaseous absorption spectrum. The only other observed photofragment, $\left[\mathrm{Ru}\left(\eta^{5}\right.\right.$ $\left.\left.\mathrm{C}_{5} \mathrm{H}_{5}\right)\left(\mathrm{PPhC}_{6} \mathrm{H}_{4}\right) \mathrm{CO}\right]^{\cdot+}$, (5b), was produced in low quantities from $\sim 4.3 \mathrm{eV}$ with a small increase between $4.8-5.2 \mathrm{eV}$, at high ion internal energies.

Fig. 6 displays the photofragmentation data as ion-yield spectra, presenting a clearer picture of the branching into the

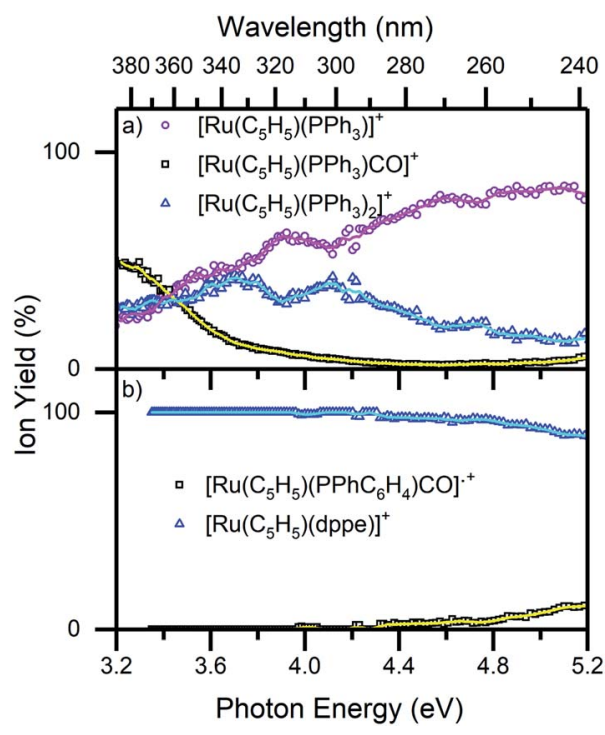

Fig. 6 lon yield spectra of the photofragments produced from (a) 1 and (b) 2 in the region between 3.2-5.2 eV. The solid lines are fivepoint adjacent averages of the data points. 
different photodissociation channels. ${ }^{37,54}$ For 1 (Fig. 6a), the loss of $\mathrm{CO}$ and $\mathrm{PPh}_{3}(4 \mathrm{a})$ is the strongest channel at all energies above $3.4 \mathrm{eV}$, but the loss of just $\mathrm{CO}(4 \mathrm{~b})$ can be seen to be enhanced at energies between $3.7-4.2 \mathrm{eV}$. At the lowest photoexcitation energies (3.2-3.4 eV), the loss of a single $\mathrm{PPh}_{3}$ ligand represents the strongest photofragmentation pathway (4c), although this channel falls away dramatically as the excitation energy, and hence, the internal energy increases. The ion yield curves for complex 2 , show that the $\left[\mathrm{Ru}\left(\eta^{5}-\mathrm{C}_{5} \mathrm{H}_{5}\right)(\mathrm{dppe})\right]^{+}$photofragment (5a), is produced with $100 \%$ yield up to $4.4 \mathrm{eV}$, decreasing to $\sim 90 \%$ ion yield at $5.2 \mathrm{eV}$, due to branching into $\left[\mathrm{Ru}\left(\eta^{5}-\mathrm{C}_{5} \mathrm{H}_{5}\right)\left(\mathrm{PPhC}_{6} \mathrm{H}_{4}\right) \mathrm{CO}\right]^{\cdot+}(5 \mathrm{~b})$.

\section{Solution-phase photolysis}

Fig. 7 shows the photolysis on $_{\text {- }}$ photolysis $_{\text {off }}$ ESI-MS obtained for photoirradiation at $365 \mathrm{~nm}$ of $\mathbf{1}$ and 2 with the photolysis cell. For 1 (Fig. 7a), solution-phase irradiation resulted in the same two main photofragments as those observed upon gas-phase irradiation, i.e., pathways (4a), and (4b), which correspond to the loss of $\mathrm{CO}$, and $\mathrm{CO}+\mathrm{PPh}_{3}$ units, respectively. The other fragment, $\left[\mathrm{Ru}\left(\eta^{5}-\mathrm{C}_{5} \mathrm{H}_{5}\right)\left(\mathrm{PPh}_{3}\right) \mathrm{CO}\right]^{+}$, produced via the loss of $\mathrm{PPh}_{3}$ from 1 (eqn (4c)), was present in the electrosprayed solution (Fig. 1a) and was photolyzed during our experiment, resulting in a negative peak.

The corresponding photolysis on - photolysis $_{\text {off }}$ mass spectrum of 2 is displayed in Fig. 7b. Upon gas-phase photoexcitation, the dominant photoproduct for this compound corresponded to ejection of $\mathrm{CO}$, and the compound can also be seen to produce the same fragment as the major photoproduct following solution-phase irradiation. A second significant intensity photoproduct is observed for this compound, which is

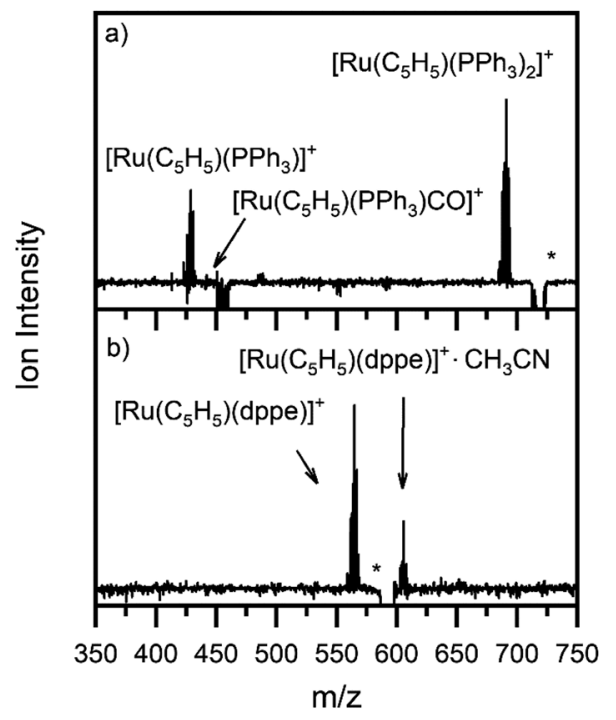

Fig. 7 Photolysis on - photolysis off $_{\text {off }}$ mass spectra of a solution of (a) $\left[\mathrm{Ru}\left(\eta^{5}-\mathrm{C}_{5} \mathrm{H}_{5}\right)\left(\mathrm{PPh}_{3}\right)_{2} \mathrm{CO}\right]\left[\mathrm{PF}_{6}\right]$ and $(\mathrm{b})\left[\mathrm{Ru}\left(\eta^{5}-\mathrm{C}_{5} \mathrm{H}_{5}\right)(\mathrm{dppe}) \mathrm{CO}\right]\left[\mathrm{PF}_{6}\right]$ after irradiation at $3.4 \mathrm{eV}$. ${ }^{*}$ indicates the parent ion. $\left[\mathrm{Ru}\left(\mathrm{C}_{2} \mathrm{H}_{5}\right)\left(\mathrm{PPh}_{3}\right)_{2}\right]^{+}$is twice the intensity of $\left[\mathrm{Ru}\left(\mathrm{C}_{2} \mathrm{H}_{5}\right)\left(\mathrm{PPh}_{3}\right)\right]^{+}$, and $\sim 20$ times that of $\left[\mathrm{Ru}\left(\mathrm{C}_{2} \mathrm{H}_{5}\right)\left(\mathrm{PPh}_{3}\right) \mathrm{CO}\right]^{+}$. $\left[\mathrm{Ru}\left(\mathrm{C}_{2} \mathrm{H}_{5}\right)(\mathrm{dppe})\right]^{+}$intensity is 2.7 times $\left[\mathrm{Ru}\left(\mathrm{C}_{2^{-}}\right.\right.$ $\left.\mathrm{H}_{5}\right)$ (dppe) $\left.\cdot \mathrm{CH}_{3} \mathrm{CN}\right]^{+}$. assigned as $\left[\mathrm{Ru}\left(\eta^{5}-\mathrm{C}_{5} \mathrm{H}_{5}\right)(\mathrm{dppe})\left(\mathrm{CH}_{3} \mathrm{CN}\right)\right]^{+}$, formed via reaction of the direct photoproduct $\left[\mathrm{Ru}\left(\eta^{5}-\mathrm{C}_{5} \mathrm{H}_{5}\right)(\mathrm{dppe})\right]^{+}$with acetonitrile traces present in the mass spectrometer inlet or trap. Similar solvent addition products were observed in online photolysis experiments performed by Arakawa et al. on bisphenanthroline complex $\left[\mathrm{Ru}(\text { phen })_{2} \mathrm{~B}\right]^{2+}$ (where phen $=1,10$ phenanthroline, $\mathrm{B}=$ ethylenediamine, trimethylenediamine, or butanediamine). ${ }^{16}$ We note that the acetonitrile adduct is not observed with $\left[\mathrm{Ru}\left(\eta^{5}-\mathrm{C}_{5} \mathrm{H}_{5}\right)\left(\mathrm{PPh}_{3}\right)\right]^{+}$. From the HCD curves (Fig. 4), it is evident that 1 and 2 display different CO binding energies, and the same would be true for an acetonitrile ligand that replaced a $\mathrm{CO}$. If acetonitrile binds more weakly to $\left[\mathrm{Ru}\left(\eta^{5}\right.\right.$ $\left.\left.\mathrm{C}_{5} \mathrm{H}_{5}\right)\left(\mathrm{PPh}_{3}\right)\right]^{+}$than $\left[\mathrm{Ru}\left(\eta^{5}-\mathrm{C}_{5} \mathrm{H}_{5}\right)(\mathrm{dppe})\right]^{+}$, the resulting complex ion might be subject to metastable decay upon electrospray or transit through the mass spectrometer.

\section{Concluding remarks}

This work has demonstrated the use of an ESI-mass spectrometry instrument to probe the gas-phase and on-line solutionphase dissociative photochemistry of two ruthenium halfsandwich complexes, $\left[\mathrm{Ru}\left(\eta^{5}-\mathrm{C}_{5} \mathrm{H}_{5}\right)\left(\mathrm{PPh}_{3}\right)_{2} \mathrm{CO}\right]^{+}$and $\left[\mathrm{Ru}\left(\eta^{5}\right.\right.$ $\left.\left.\mathrm{C}_{5} \mathrm{H}_{5}\right)(\mathrm{dppe}) \mathrm{CO}\right]^{+}$. Each compound was found to follow the same primary photofragmentation pathway i.e., loss of $\mathrm{CO}+\mathrm{PPh}_{3}$ ligands from $\left[\mathrm{Ru}\left(\eta^{5}-\mathrm{C}_{5} \mathrm{H}_{5}\right)\left(\mathrm{PPh}_{3}\right)_{2} \mathrm{CO}\right]^{+}$and loss of just $\mathrm{CO}$ from $\left[\mathrm{Ru}\left(\eta^{5}-\mathrm{C}_{5} \mathrm{H}_{5}\right)(\mathrm{dppe}) \mathrm{CO}\right]^{+}$, both in solution and in the gas phase.

It is useful to discuss the potential benefits of using a single instrument to obtain consecutive gaseous and on-line solutionphase photolysis measurements. First, one clear benefit of conducting solution-phase photolysis to complement the gasphase measurement, lies in being able to test the relevance of the gaseous results to the more widely-encountered solutionphase environment, where the majority of photochemistry occurs. For systems such as the compounds studied here where the solution and gas-phase photoproducts are the same, the gas-phase production profiles are likely to map those in solution, allowing the single-wavelength diode measurement to be extrapolated to other photoexcitation energies.

From the opposite perspective, what is the benefit of the gasphase measurement in addition to on-line photolysis? Since the gas-phase measurement is effectively a mass-selective spectroscopic measurement, the precursor species that produces the measured photoproducts is unambiguous. This provides clarity around a number of issues that can complicate solution-phase measurements, including the effect of charge state and aggregation. An additional benefit of performing photodissociation in the gas phase is that the measurement is effectively background free, allowing the detection of very low yield photoproducts. Finally, as the gaseous measurements are performed in the absence of solvent, the direct photoproducts can be identified, with clarity that secondary solvent reactions, or reactions of an excited state molecule with a second precursor molecule are not involved in their formation. This third point illustrates the important synergy for photochemical mechanistic studies which results from doing both gas-phase and solution-phase measurements consecutively, since comparison of the two sets of results allows delineation of mechanisms of 
photoproduct formation where solvent is involved from those where it is not. ${ }^{14}$

In summary, by linking an on-line photolysis source with a laser-interfaced mass spectrometer, we have demonstrated an instrument that can be used to consecutively characterise photochemical mechanisms in solution and gas phase. The dissociative photochemistry of a pair of CO-releasing ruthenium half-sandwich complexes was characterised using this setup. On-line diode photolysis provides an efficient and rapid tool for photoreaction screening, while the laser interfaced mass spectrometry measurements provide insight into the wavelength-dependent photochemistry across a broad excitation range. This approach could be widely applied to photochemical processes of emerging interest, such as light-activated prodrugs, ${ }^{55,56}$ photocatalysts, ${ }^{12-14}$ and environmental pollutants. $^{57,58}$

\section{Conflicts of interest}

There are no conflicts of interest to declare.

\section{Acknowledgements}

Acknowledgment is made to the Leverhulme Trust for support of this work through research project grant RPG-2017-147. We thank the University of York and the Department of Chemistry for funding the Horizon OPO laser system, and York Advanced Computing Cluster (YARCC) for access to computational resources. The York Centre of Excellence in Mass Spectrometry, which was used for the HCD work, was created thanks to a major capital investment through Science City York, supported by Yorkshire Forward with funds from the Northern Way Initiative, and subsequently additional support received from the EPSRC. We also thank Karl Heaton and Dr Ed Bergström for valuable discussions.

\section{References}

1 T. P. Yoon, M. A. Ischay and J. Du, Nat. Chem., 2010, 2, 527532.

2 D. M. Schultz and T. P. Yoon, Science, 2014, 343, 1239176.

3 L. Buzzetti, G. E. M. Crisenza and P. Melchiorre, Angew. Chemie Int. Ed., 2019, 58, 3730-3747.

4 C. T. Middleton, K. de La Harpe, C. Su, Y. K. Law, C. E. Crespo-Hernández and B. Kohler, Annu. Rev. Phys. Chem., 2009, 60, 217-239.

5 E. T. J. Nibbering, H. Fidder and E. Pines, Annu. Rev. Phys. Chem., 2005, 56, 337-367.

6 Y. Ji, D. A. DiRocco, J. Kind, C. M. Thiele, R. M. Gschwind and M. Reibarkh, ChemPhotoChem, 2019, 3, 984-992.

7 S. Dall'Acqua, G. Miolo, G. Innocenti and S. Caffieri, Molecules, 2012, 17, 8898-8907.

8 C. Furlan, J. A. Berenbeim and C. E. H. Dessent, Molecules, 2020, 25, 5280.

9 M. N. Eberlin, Eur. J. Mass Spectrom., 2007, 13, 19-28.

10 K. L. Vikse, Z. Ahmadi and J. Scott McIndoe, Coord. Chem. Rev., 2014, 279, 96-114.
11 J. Mehara and J. Roithová, Chem. Sci., 2020, 11, 11960-11972. 12 S. Chen, Q. Wan and A. K. Badu-Tawiah, Angew. Chem. Int. Ed., 2016, 55, 9345-9349.

13 Y. Cai, J. Wang, Y. Zhang, Z. Li, D. Hu, N. Zheng and H. Chen, J. Am. Chem. Soc., 2017, 139, 12259-12266.

14 J. Zelenka and J. Roithová, ChemBioChem, 2020, 21, 22322240.

15 B. J. Aucott, A.-K. Duhme-Klair, B. E. Moulton, I. P. Clark, I. V. Sazanovich, M. Towrie, L. A. Hammarback, I. J. S. Fairlamb and J. M. Lynam, Organometallics, 2019, 38, 2391-2401.

16 R. Arakawa, K. Abe, M. Iwai, T. Fukuo and Y. Nakabayashi, J. Mass Spectrom. Soc. Jpn., 2001, 49, 183-187.

17 C. A. Turner, W. Ding, I. J. Amster and C. Kutal, Coord. Chem. Rev., 2002, 229, 9-16.

18 I. S. Camacho, A. Theisen, L. O. Johannissen, L. A. DíazRamos, J. M. Christie, G. I. Jenkins, B. Bellina, P. Barran and A. R. Jones, Proc. Natl. Acad. Sci. U. S. A., 2019, 116, 1116-1125.

19 M. A. Duncan, Int. J. Mass Spectrom., 2000, 200, 545-569.

20 S. M. J. Wellman and R. A. Jockusch, Chem. -Eur. J., 2017, 23, 7728-7736.

21 C. Kjær and S. Brøndsted Nielsen, Phys. Chem. Chem. Phys., 2019, 21, 4600-4605.

22 U. Jacovella, E. Carrascosa, J. T. Buntine, N. Ree, K. V. Mikkelsen, M. Jevric, K. Moth-Poulsen and E. J. Bieske, J. Phys. Chem. Lett., 2020, 11, 6045-6050.

23 P. Gautam and B. M. Bhanage, Catal. Sci. Technol., 2015, 5, 4663-4702.

24 J. B. Peng, F. P. Wu and X. F. Wu, Chem. Rev., 2019, 119, 2090-2127.

25 C. Daniel, Coord. Chem. Rev., 2015, 282-283, 19-32.

26 Y. Yamazaki, H. Takeda and O. Ishitani, J. Photochem. Photobiol., C, 2015, 25, 106-137.

27 A. Sinopoli, N. T. La Porte, J. F. Martinez, M. R. Wasielewski and M. Sohail, Coord. Chem. Rev., 2018, 365, 60-74.

28 P. L. Cheung, C. W. Machan, A. Y. S. Malkhasian, J. Agarwal and C. P. Kubiak, Inorg. Chem., 2016, 55, 3192-3198.

29 L. A. Hammarback, B. J. Aucott, J. T. W. Bray, I. P. Clark, M. Towrie, A. Robinson, I. J. S. Fairlamb and J. M. Lynam, J. Am. Chem. Soc., 2021, 143, 1356-1364.

30 L. A. Hammarback, I. P. Clark, I. V. Sazanovich, M. Towrie, A. Robinson, F. Clarke, S. Meyer, I. J. S. Fairlamb and J. M. Lynam, Nat. Catal., 2018, 1, 830-840.

31 R. Motterlini, J. E. Clark, R. Foresti, P. Sarathchandra, B. E. Mann and C. J. Green, Circ. Res., 2002, 90, e17-e24.

32 R. Motterlini and L. E. Otterbein, Nat. Rev. Drug Discovery, 2010, 9, 728-743.

33 B. Chen, L. Guo, C. Fan, S. Bolisetty, R. Joseph, M. M. Wright, A. Agarwal and J. F. George, Am. J. Pathol., 2009, 175, 422429.

34 A. Pamplona, A. Ferreira, J. Balla, V. Jeney, G. Balla, S. Epiphanio, Â. Chora, C. D. Rodrigues, I. P. Gregoire, M. Cunha-Rodrigues, S. Portugal, M. P. Soares and M. M. Mota, Nat. Med., 2007, 13, 703-710.

35 N. Fujisaki, K. Kohama, T. Nishimura, H. Yamashita, M. Ishikawa, A. Kanematsu, T. Yamada, S. Lee, T. Yumoto, 
K. Tsukahara, J. Kotani and A. Nakao, Med. Gas Res., 2016, 6, 122-129.

36 L. S. Nobre, H. Jeremias, C. C. Romão and L. M. Saraiva, Dalt. Trans., 2016, 45, 1455-1466.

37 R. Cercola, K. C. Fischer, S. L. Sherman, E. Garand, N. G. K. Wong, L. A. Hammerback, J. M. Lynam, I. J. S. Fairlamb and C. E. H. Dessent, Chem. -Eur. J., 2020, 26, 10297-10306.

38 T. Ikariya and A. J. Blacker, Acc. Chem. Res., 2007, 40, 13001308.

39 N. U. Din Reshi, D. Senthurpandi and A. G. Samuelson, J. Organomet. Chem., 2018, 866, 189-199.

40 X. Qiao, D. Qiu, N. Lin, J. Zhu, W. Deng and Z. Yao, Appl. Organomet. Chem., 2019, 33, e4875.

41 D. G. Johnson, J. M. Lynam, N. S. Mistry, J. M. Slattery, R. J. Thatcher and A. C. Whitwood, J. Am. Chem. Soc., 2013, 135, 2222-2234.

42 F. J. Ballester, E. Ortega, V. Porto, H. Kostrhunova, N. DavilaFerreira, D. Bautista, V. Brabec, F. Domínguez, M. D. Santana and J. Ruiz, Chem. Commun., 2019, 55, 1140-1143.

43 P. C. A. Bruijnincx and P. J. Sadler, Adv. Inorg. Chem., 2009, 61, 1-62.

44 I. Chakraborty, S. J. Carrington and P. K. Mascharak, Acc. Chem. Res., 2014, 47, 2603-2611.

45 M. Fumanal, E. Gindensperger and C. Daniel, J. Phys. Chem. Lett., 2018, 9, 5189-5195.

46 E. Borfecchia, C. Garino, L. Salassa and C. Lamberti, Philos. Trans. R. Soc., A, 2013, 371, 20120132.
47 E. Matthews, A. Sen, N. Yoshikawa, E. Bergström and C. E. H. Dessent, Phys. Chem. Chem. Phys., 2016, 18, 15143-15152.

48 N. G. K. Wong, J. A. Berenbeim, M. Hawkridge, E. Matthews and C. E. H. Dessent, Phys. Chem. Chem. Phys., 2019, 21, 14311-14321.

49 N. S. Mistry, Mechanistic Studies into the Catalytic Activity of Half-Sandwich Ruthenium Complexes, University of York, 2013.

50 A. Sen, T. F. M. Luxford, N. Yoshikawa and C. E. H. Dessent, Phys. Chem. Chem. Phys., 2014, 16, 15490-15500.

51 R. Cercola, E. Matthews and C. E. H. Dessent, J. Phys. Chem. $B, 2017,121,5553-5561$.

52 K. Koike, N. Okoshi, H. Hori, K. Takeuchi, O. Ishitani, H. Tsubaki, I. P. Clark, M. W. George, F. P. A. Johnson and J. J. Turner, J. Am. Chem. Soc., 2002, 124, 11448-11455.

53 E. Crawford, P. J. Dyson, O. Forest, S. Kwok and J. S. McIndoe, J. Clust. Sci., 2006, 17, 47-63.

54 N. G. K. Wong, C. D. Rankine and C. E. H. Dessent, J. Phys. Chem. Lett., 2021, 12, 2831-2836.

55 B. Yu, Y. Zheng, Z. Yuan, S. Li, H. Zhu, L. K. De La Cruz, J. Zhang, K. Ji, S. Wang and B. Wang, J. Am. Chem. Soc., 2018, 140, 30-33.

56 C. Imberti, P. Zhang, H. Huang and P. J. Sadler, Angew. Chemie Int. Ed., 2020, 59, 61-73.

57 N. G. K. Wong, J. A. Berenbeim and C. E. H. Dessent, ChemPhotoChem, 2019, 3, 1231-1237.

58 W. H. M. Abdelraheem, X. He, Z. R. Komy, N. M. Ismail and D. D. Dionysiou, Chem. Eng. J., 2016, 288, 824-833. 